\title{
The Role of Teachers in Implementing Curriculum 13 in Primary Schools
}

\author{
Basarun Saleh $^{1 *}$, Yasir Arafat ${ }^{2}$, Alhadi Yan Putra ${ }^{2}$ \\ ${ }^{1}$ SD Negeri 07, Sinar Mulyo, Simpang OKU Selatan, South of Sumatera, Indonesia \\ ${ }^{2}$ Universitas PGRI Palembang, Indonesia \\ *Corresponding author. Email: basarun1972@gmail.com
}

\begin{abstract}
The research was conducted by looking at the condition of the results of the teaching and learning process. This study aimed to determine the effect of tutoring and the role of parents on student learning outcomes at State Elementary School 07, Sinar Mulyo Village, Simpang District, South OKU Regency. This research uses quantitative methods with a population of 320 and a sample of 177 respondents, with data collection techniques using questionnaires and documentation of student learning outcomes, then tested with SPSS version 2.5 at the $5 \%$ significance level using the t-test. The conclusion that $\mathrm{H} 1$ is accepted shows that there is an effect of $85.2 \%$. For $\mathrm{H} 2$ to be accepted, this indicates that there is an effect of $62.3 \%$. To test the effect simultaneously, the F-test is used, resulting in acceptable H3, with a large effect of $40.6 \%$. The implication of this research is used as input for teachers and parents to pay attention to the development of learning outcomes for their children.
\end{abstract}

Keywords: Role, Teacher, Curriculum 2013

\section{INTRODUCTION}

Education is something that has a very important purpose to obtain. In achieving educational goals, students as educational subjects can be directed to formal and informal education.

According to Winataputra [1] In undergoing the learning process, students need help and guidance from others. Realized or not, the teachers in all teaching fields are implied to a form of guidance that helps students to overcome difficulties in arithmetic. Teachers show the student how to improve completion and reread the lesson assignment, advising students to be respectful and friendly to others is an activity or act of guidance. One form of guidance is tutoring.

According to Eriany [2], problems arise when schools must be done, and the growing development of education, such as from the development of technology and educational facilities, more and more students do not have the motivation to learn and receive guidance from their teachers. This is evidenced by the number of students who like to play truant, arrive late, do not do homework, and show inappropriate attitudes.

This makes researchers interested in researching the effect of tutoring and parental guidance in influencing student learning outcomes at State Elementary School 07 Sinar Mulyo Village, Simpang Sub-District, OKU Selatan Regency. A fairly comprehensive understanding of learning is given, which states that learning is a process carried out by humans to get various competencies, skills, and attitudes. These competencies, skills, and attitudes are acquired gradually and continuously from infancy to old age through a series of lifelong learning processes.

According to Azhar [3], learning is anything that can bring information and knowledge in the interactions between educators and students. So that learning is a long process in order to achieve more results. To achieve this result requires the right strategy.

It is very clear to us that learning is about the amount of knowledge and includes all the abilities of the individual. The last two definitions focus their attention on three things (1) Learning must allow behaviour change to occur in individuals; (2) the change must be the fruit of experience; and (3) the changes are relatively persistent

Regarding to the learning process that occurs in students, it suggests eight types of learning. The eight types of learning are: namely (1) Learning Signs; (2) Stimulus-Response; (3) Learning sequences; (4) 
Learning verbal associations; (5) Learn to differentiate; (6) Learning concepts; (7) Studying laws and regulations; (8) Learning problem solving [1].

Student learning outcomes indicate these students' ability and quality through the learning process they are going through. The existence of quality student learning outcomes can be produced through a quality learning process with educators who have the ability to apply learning methods according to student needs [4].

Learning outcomes can be interpreted as the maximum results achieved by a student after experiencing the teaching and learning process in learning certain subject matter. Learning outcomes are not absolutely in the form of values, but can be in the form of changes, reasoning, discipline, skills and so on that lead to positive changes [5].

David R. Krathwohl and colleagues originally issued the taxonomy for the affective area in a book entitled "taxonomy of educational objective: affective domain". The affective domain is a domain in which a person's attitude can predictably change if a person has highlevel cognitive mastery. The type of affective learning outcomes will appear in students in a variety of behaviours

One scientist expressed his opinion that what is meant by guidance is: A process of providing continuous and systematic assistance from the mentor to the guided so that independence can be achieved in selfunderstanding and self-realization, in achieving a maximum and optimal level of development and adjustment to the environment [6].

According to Kamalik [7], tutoring functions include: (1) Providing assistance to clients (students) to obtain an objective and clear picture of their potential, character, interests, attitudes and so on; (2) Assisting students to obtain education in accordance with their needs, talents, interests and abilities; and (3) Helping individuals (students) to get a clear picture of the possibilities and trends that will occur in the work field so that they can make the right choices.

Guidance is the process of providing assistance by an expert to a person or several individuals, including children, adolescents, and adults, so that the person being guided can develop their own abilities and be independent; by utilizing individual strengths and existing means that can be developed and applied in society [9].

Whereas what is meant by the role of parents is as a process of providing assistance to individuals that is carried out continuously, so that the individual can understand himself, so that he is able to direct himself and can act naturally, in accordance with the guidance and conditions of the school environment, family and community, and life. in general [10].
According to Winataputra [1], parents' duties towards children are not only limited to feeding, drinking, buying new clothes, and a comfortable shelter. However, several things need to be considered in educating children. What needs to be considered is instilling a view of religious life in childhood in the family, knowing the basics of family responsibility for children's education, whether in the family environment the child can develop various abilities, and what can be done in developing the child's abilities [1].

According to Poerwadarminta [11], this role's definition is an action taken by a person based on the events that are behind it. These events or incidents can be in good terms as well as bad things according to the environment that is influencing him to act.

\section{METHODS}

This research method, quantitative, can also be interpreted as a research method based on the philosophy of positivism, used to research certain populations or samples, data collection using research instruments, quantitative / statistical data analysis, and the aim of testing predetermined hypotheses.

The research hypotheses are (1) Accepted if there is an effect of tutoring on student learning outcomes of State Elementary School 07 Sinar Mulyo Village, Simpang Sub-District, OKU Selatan Regency; (2) Accepted if there is an influence of the role of parents on learning outcomes State Elementary School 07 Sinar Mulyo Village, Simpang Sub-District, OKU Selatan Regency; and (3) Accepted if there is an effect of tutoring and parental guidance on student learning outcomes of State Elementary School 07 Sinar Mulyo Village, Simpang Sub-District, OKU Selatan Regency

The result stage of data processing will be interpreted in the form of analysis to build a conclusion in response to the research objectives. In this study, analysis was carried out on descriptive analysis and analysis of the research hypothesis.

\section{RESULTS AND DISCUSSION}

\section{Hypothesis testing $1\left(\mathrm{H}_{1}\right)$}

The tutoring variable in research at SState Elementary School 07 Sinar Mulyo Village, Simpang Sub-District, OKU Selatan Regency, South Sumatra Province was measured using a Likert scale questionnaire of 23 statement items. Tutoring score scores range from 23 to 115 . 


\begin{tabular}{|c|c|c|c|c|c|c|}
\hline & & & Table 1 & Hypothesis 1 & & \\
\hline & Iodel & $\begin{array}{l}\text { Unstanc } \\
\text { Coeff }\end{array}$ & $\begin{array}{l}\text { Irdized } \\
\text { ients }\end{array}$ & $\begin{array}{l}\text { Standardized } \\
\text { Coefficients }\end{array}$ & $\mathrm{t}$ & Sig. \\
\hline & & B & $\begin{array}{l}\text { Std. } \\
\text { Error }\end{array}$ & Beta & & \\
\hline 1 & (Constant) & 642.898 & 40.632 & & 15.823 & 0.000 \\
\hline & tutoring & -0.463 & 0.414 & 0.314 & 2.3646 & 0.038 \\
\hline
\end{tabular}

a. Dependent Variable: learning outcomes

It is known that the significance value for the effect of variable $\mathrm{X}_{1}$ on variable $\mathrm{Y}$ is $0.038<0.05$ and tcount2.3646> table 1.9552. Thus, it can be concluded that H01 is accepted.

\section{Hypothesis testing $2\left(\mathrm{H}_{2}\right)$}

Hypothesis 2 will be accepted if there is an influence of social media on student learning outcomes of State Elementary School 07 Sinar Mulyo Village, Simpang Sub-District, OKU Selatan Regency, provided that the significance value is $\langle 0.05$, and $\mathrm{t}$-count $\rangle \mathrm{t}$ table.

Table 2. Hypothesis testing 2

Unstandardized Standardized

Coefficients Coefficients

\begin{tabular}{|c|c|c|c|c|c|}
\hline Model & B & $\begin{array}{l}\text { Std. } \\
\text { Error }\end{array}$ & Beta & $\mathrm{t}$ & Sig. \\
\hline 1 (Constant) & 620.155 & 52.691 & & 11.770 & 0.000 \\
\hline $\begin{array}{l}\text { the role of } \\
\text { parents }\end{array}$ & -0.149 & 0.348 & 0.215 & 4.75362 & 0.0137 \\
\hline
\end{tabular}

a. Dependent Variable: learning outcomes

Hypothesis 3 will be accepted if there is an influence

It is known that the significance value is 0.0137 $<0.05$ and the t-count value is 4.75362>t table 1.98552, thus it can be concluded that $\mathrm{Ho} 2$ is accepted.

\section{Hypothesis testing $3\left(\mathrm{H}_{3}\right)$}

of social media on student learning outcomes of State Elementary School 07 Sinar Mulyo Village, Simpang Sub-District, OKU Selatan Regency, provided that the significance value is $<0.05$, and F-count $>\mathrm{t}$ table.

Table 3. Hypothesis testing 3

\begin{tabular}{|c|c|c|c|c|c|}
\hline Model & $\begin{array}{l}\text { Sum of } \\
\text { Squares }\end{array}$ & df & $\begin{array}{c}\text { Mean } \\
\text { Square }\end{array}$ & $\mathrm{F}$ & Sig. \\
\hline 1 Regression & 2614.283 & 2 & 1307.141 & 12.267 & $.016^{\mathrm{b}}$ \\
\hline Residual & 10439.938 & 101 & 103.365 & & \\
\hline Total & 13054.221 & 103 & & & \\
\hline
\end{tabular}

a. Dependent Variable: learning outcomes

b. Predictors: (Constant), tutoring, the role of parents

It is known that the significance value is Sig. 0.016 $<0.05$, and F counting 12.267> F table 3.09, it can be concluded that there is an effect of variable $\mathrm{X}_{1}$ and variable $\mathrm{X} 2$ simultaneously on variable $\mathrm{Y}$.

The results of this study are consistent with the research conducted by Sari [9]. In his research, it shows that tutoring affects students' mathematics learning outcomes. This is indicated by the calculation of the Ttest, which results in the sig value. (2-tailed) 0.000
$<0.05$, which indicates a significant difference between students' mathematics learning outcomes before and after being given tutoring services.

This research is in line with the research on the role of parents on the achievement of Grade 5 students at SD Al-Azhar Syifabudi Pekanbaru, in the Journal of Eendurance 2 (1) in 2017. The results obtained from the study showed that of the 63 student parents, 62 students (98.4\%) have done its role well. The good role of parents is influenced by several factors, one of which is 
the factor of parental education. From the data obtained, the parent's education level of 5th-grade students at SD Al Azhar Syifabudi is high school and university (63 people).

In line with the results of this study, it is explained in the results of the study the effect of learning discipline and parental guidance on mathematics learning achievement in Class VIII students of SMP Negeri 2 Mondokan in the 2010/2011 academic year, namely testing the third hypothesis with the F test obtaining the value of Fcount> Ftable, namely 34.270> 3.085, it means that together learning discipline and parental guidance have a positive effect on mathematics learning achievement.

\section{CONCLUSION}

From this research, the conclusions are (1) The existence of tutoring for student learning outcomes of State Elementary School 07 Sinar Mulyo Village, Simpang Sub-District, OKU Selatan Regency; (2) The influence of the role of parents on student learning outcomes of State Elementary School 07 Sinar Mulyo Village, Simpang Sub-District, OKU Selatan Regency; and (3) the mutual influence of tutoring and the role of parents on State Elementary School 07 Sinar Mulyo Village, Simpang Sub-District, OKU Selatan Regency.

\section{ACKNOWLEDGMENTS}

Our deepest gratitude goes to Teachers in SD Negeri 07, Sinar Mulyo Village, Simpang OKU Selatan District, Chancellor of Palembang PGRI University, Director of the Postgraduate Program of PGRI Palembang University and the Education Management Study Program of PGRI Palembang University, who have supported us in doing this extraordinary thing. This project is funded independently. We also want to thank our Education Management friends who helped us a lot in a short time frame to complete this project.

\section{REFERENCES}

[1] Winataputra, U. S., Delfi, R., Pannen, P., \& Mustafa, D. (2014). Hakikat Belajar dan Pembelajaran. Hakikat Belajar dan Pembelajaran, $1-46$.

[2] Eriany, P., Hernawati, L., \& Goeritno, H. (2014). Studi deskriptif mengenai faktor-faktor yang mempengaruhi motivasi mengikuti kegiatan bimbingan belajar pada siswa smp di semarang. Psikodimensia, 13(1), 115.

[3] Azhar, A. (2011). Media pembelajaran. Jakarta: Rajawali Pers.

[4] Nasution, M. K. (2018). Penggunaan metode pembelajaran dalam peningkatan hasil belajar siswa. Studia Didaktika, 11(01), 9-16.
[5] Turrohmah, M. (2017). Hubungan kompetensi profesional guru Qur'an hadist dan motivasi belajar terhadap hasil belajar siswa di Ma Nurul Ulum Tulungagung Kec Gading Rejo Kab Pringsewu. UIN Raden Intan Lampung.

[6] Maslikhah, M. (2019). Bimbingan kelompok menggunakan metode cooperative learning dalam meningkatkan motivasi belajar siswa sekolah dasar di bekasi. Tunas Bangsa Journal, 6.

[7]. Nurhidayanti, T. D. (2019). Pengaruh bimbingan belajar melalui makna pelafalan Man Jadda Wajada terhadap peningkatan motivasi belajar siswa di SMP Binar Ilmu Cimenyan Kabupaten Bandung. UIN Sunan Gunung Djati Bandung.

[8] Prayitno, E. A., \& Amti, E. (2004). Dasar-dasar bimbingan dan konseling. Jakarta: Rineka Cipta.

[9] Sari, Y. W. (2015). Pengaruh Bimbingan Belajar terhadap Hasil Belajar Matematika Siswa kelas IV di Sekolah Dasar. Jurnal Penelitian Pendidikan Guru Sekolah Dasar, 3(2).

[10] Yusuf, S., \& Nurihsan, A. J. (2006). Landasan Bimbingan dan Konseling, Bandung: PT. Remaja Rosdakarya.

[11] Wibowo, B. (2016). Analisis perlakuan akuntansi atas aset tetap pada cv tri bhakti jaya palembang. Politeknik negeri sriwijaya. 